$5 \quad$ Title page

\title{
6 Are island plants really poorly defended? No \\ 7 support for the loss of defense hypothesis in \\ 8 domatia-bearing plants
}

$9 \quad$ M. Biddick ${ }^{*}$

10

$11{ }^{1}$ Terrestrial Ecology Research Group

12 Technical University of Munich

13 Freising, Germany.

14 https://orcid.org/0000-0002-1196-5698

15

16 Correspondence: matt.biddick@tum.de

17

18 Running title: LOSS OF DEFENSE IN PLANTS

19 Article type: Research article

20 Abstract: 139 words.

21 Main text: 1502 words.

22 References: 30

23 Figures: 2 


\section{LOSS OF DEFENSE IN PLANTS}

\section{1. Abstract}

The loss of defense hypothesis posits that island colonizers experience a release from predation on the mainland and subsequently lose their defensive adaptations. While support for the hypothesis is abundant, it has never been tested in domatia-bearing plants. Leaf domatia are cave-like structures produced on the underside of leaves that facilitate a defensive mutualism with predatory and fungivorous mites. I tested the loss of defense hypothesis in six domatia-bearing taxa inhabiting New Zealand and its offshore islands. No support for the loss of defense hypothesis was found. Changes in domatia investment were instead associated with changes in leaf size - a trait that has been repeatedly observed to undergo rapid evolution on islands. Overall results demonstrate that not all types of defense are lost on islands, suggesting a higher-resolution approach is needed when studying the evolution of defense on islands.

Key words: plant defense; island syndrome; insular evolution; New Zealand; plant-arthropod mutualism.

\section{Introduction}

Island organisms can often differ from their mainland counterparts in remarkable yet predictable ways. Collectively, these ecological, morphological, and behavioural differences comprise what is known as the 'island syndrome' [1-3]. One of the most remarkable trends comprising the island syndrome is the loss of defensive adaptations. The loss of defense hypothesis posits that island organisms lose defensive adaptations after colonizing isolated islands because they no longer provide a fitness benefit in the absence of mainland predators [4]. For instance, many endemic island birds like the Dodo of Mauritius exhibit no fear of mammalian predators - including humans (unfortunately to their detriment). In fact, almost half of the endemic avifauna of the New Zealand archipelago went extinct following the introduction of mammalian predators $[5,6]$. Similar behavioural shifts are seen in other prey taxa like insular foxes, wallabies, and lizards [7, 8]. However, defensive adaptations are not only lost in island animals. change in response to the absence of mainland predators in their new environment, plants change in response to absent mainland herbivores [11]. Leaf spines, for example, are 


\section{LOSS OF DEFENSE IN PLANTS}

56

\section{3. Methods}

\section{7 (a) Data collection} islands (figure 1).

effective physical deterrents of grazing ungulates like deer and cattle [12, 13]. However, on the California Channel Islands where ungulates have historically been absent (until recent introductions), many endemic plants produce larger leaves, fewer spines, and less phenol compounds than their most closely related mainland sister taxa [14]. Another remarkable loss of defense is seen in Pseudopanax crassifolius (lancewood) from New Zealand. Lancewood saplings produce long, hardened leaves with lateral leaf spines that are advertised with aposematic colouration [15]. Thought to deter large (now extinct) browsing birds called Moa [16], these morphological adaptations have been lost in populations of $P$. crassifolius inhabiting the Chatham Islands some 800km away (where Moa were absent) [17]. However, not all forms of plant defense are physical.

Some plants produce cave-like structures on the underside of their leaves known as domatia that facilitate a defensive mutualism with predatory and fungivorous mites $[18,19]$. Leaf domatia provide a refuge for oviposition and shelter from the environmental extremes of leaf surfaces, which mites in turn protect via the consumption of herbivorous arthropods and fungal pathogens [20]. Some 2000 taxa of domatia-bearing plants belonging to 227 plant families have been described [21]. Intriguingly, no study has documented whether this defensive mutualism is lost on islands. To test this formally, I quantified domatia production in six cosmopolitan taxa inhabiting the New Zealand mainland and its surrounding offshore

Data collection was conducted between June 2018 and April 2019. Individuals were chosen haphazardly while walking through easily accessible forest sections. Only fully expanded, mature leaves were measured. Leaf length was measured as the longest linear distance from the most proximal to the most distal point of the leaf lamina using a digital calliper. Leaf width was measured as the widest distance across the leaf lamina perpendicular to the leaf length measurement. Leaf area was calculated as the product of leaf length and leaf width. Although more accurate methods of estimating leaf area exist [e.g., using leaf shape correction factors or leaf scanners, 22]), leaf $x$ width calculations sufficed for the purpose of this analysis as it is not concerned with among species differences in leaf size. Couched in 


\section{LOSS OF DEFENSE IN PLANTS}

\section{3 (b) Data analysis}

104 To test for mainland-island differences in domatia production, I conducted species-wise

105 Welch $t$-tests. Data were left untransformed as the Welch $t$-test is robust to violations of

\section{4. Results}

111 No evidence for the loss of defense hypothesis was observed, with 2 taxa exhibiting

112 marginally reduced domatia production under insular conditions, 2 taxa exhibiting no change,

113 and 2 taxa showing increased domatia production (table 1, figure 2). Island populations of $C$.

114 rhamnoides exhibited marginally higher rates of domatia production relative to mainland

115 populations. Changes in domatia production were instead associated with changes in leaf size

$$
\text { on islands (table 1). }
$$




\section{LOSS OF DEFENSE IN PLANTS}

117 Table 1. Results of species-wise Welch t-tests analysing mainland-island population differences in

118 leaf size and domatia production. Samples sizes are denoted in parentheses for mainland and island

119 populations, respectively. Significant $p$-values $\leq 0.05$ are denoted in italics.

\begin{tabular}{lcccccc}
\hline \multirow{2}{*}{ species } & \multicolumn{3}{c}{ leaf size } & \multicolumn{3}{c}{ leaf domatia } \\
\cline { 2 - 7 } & $\boldsymbol{T}$ & $\boldsymbol{p}$ & $\begin{array}{c}\text { insular } \\
\text { change }\end{array}$ & $\boldsymbol{T}$ & $\boldsymbol{p}$ & $\begin{array}{c}\text { insular } \\
\text { change }\end{array}$ \\
\hline $\begin{array}{l}\text { Coprosma repens }(30,332) \\
\text { Coprosma rhamnoides }(64,\end{array}$ & -6.81 & $<0.01$ & decrease & -2.44 & 0.02 & decrease \\
204) & 9.77 & $<0.01$ & increase & 1.93 & 0.05 & increase \\
Coprosma robusta $(52,60)$ & 2.34 & 0.02 & increase & -1.49 & 0.14 & no change \\
Coprosma lucida $(62,245)$ & 4.42 & $<0.01$ & increase & 2.56 & 0.01 & increase \\
Elaeocarpus dentatus $(80,89)$ & 0.88 & 0.38 & no change & -2.49 & 0.02 & reduce \\
Vitex lucens $(30,36)$ & 4.43 & $<0.01$ & increase & 0.82 & 0.42 & no change \\
\hline
\end{tabular}

\section{5. Discussion}

122 Many previous studies have documented the loss of defense adaptations in island organisms, 123 and loss of defense is considered more generally to constitute part of the 'island syndrome'

124 [1-3]. However, findings from this study demonstrate that not all types of defense are lost on 125 islands. Only a marginal reduction in leaf domatia production was observed in two of the six

126 taxa considered. The remaining taxa either showed no change or, contrastingly, increased

127 domatia production on islands.

128 Why aren't leaf domatia lost on islands? The putative explanation for defense loss in 129 island organisms is the absence of mainland predators. For instance, mammals are typically

130 poor dispersers and thereby lack the ability to colonize remote islands. Plants that have

131 historically been defended against such mammalian predators, and subsequently colonize

132 isolated islands, are freed from this predation pressure, and no longer benefit from the

133 production of physical deterrents like thorns, spines, and prickles. The mites inhabiting leaf

134 domatia, on the other hand, protect plants against insect and fungal attack - both of which

135 disperse readily to islands [24].

Another potential explanation is that the islands considered in this study, and the flora

137 inhabiting them, are too young to exhibit the loss of defense phenomenon. Indeed, previous

138 work has demonstrated the effect of island age and time since divergence on phylogeographic

139 patterns $[25,26]$. Most of the islands considered here are continental break offs from the

140 larger New Zealand landmass. As such, they are relatively young in comparison to true

141 oceanic islands like Hawaii or Mauritius. This could explain why a marginal decrease in 


\section{LOSS OF DEFENSE IN PLANTS}

142 domatia production was observed in some taxa. Further, many islands are only weakly

143 isolated from the New Zealand mainland, such that gene flow between island and mainland

144 populations may exist, dampening the signal of an otherwise real effect [see 27 for

145 discusssion].

146 Contrary to the loss of defense hypothesis, changes in domatia production were

147 instead associated with changes in leaf size on islands. Prior work has demonstrated that leaf

148 size in woody plants obeys the island rule [28] - a ubiquitous pattern in island evolution

149 whereby species converge on intermediate sizes on islands. Changes in domatia production in

150 island populations may therefore be explained by changes in leaf size if both traits are

151 allometrically related (though allometrically-linked traits have been shown to evolve

152 independently [29]).

In conclusion, island plants are not 'poorly defended' per se. Rather, they tend to lose adaptations to predators and competitors that are absent on the isolated islands they colonize. Because insect and fungal attack are still very much a threat on islands, the mutualistic relationship of plants with predacious and fungivorous mites facilitated by leaf domatia remains advantageous. Future work should test whether other types of defensive mutualisms are lost or reduced on islands, such as those with ants. Finally, the loss of defense hypothesis should be amended to reflect changes in defense rather than its loss. While island endemics are often poorly defended against introduced mammalian predators, many are exceptionally well protected against (now extinct) avian predators [30].

\section{Data accessibility}

165 Data related to this article can be found at doi:10.5061/dryad.rv15dv48q.

166 Author contributions

167 M.B collected the data, conducted analyses, and wrote the manuscript.

\section{Competing interests}

169 The author declares no competing interests. 
bioRxiv preprint doi: https://doi.org/10.1101/2021.11.11.468197; this version posted November 12, 2021. The copyright holder for this preprint (which was not certified by peer review) is the author/funder, who has granted bioRxiv a license to display the preprint in perpetuity. It is made available under aCC-BY-NC-ND 4.0 International license.

\section{LOSS OF DEFENSE IN PLANTS}

M.B is generously funded by the Alexander von Humboldt Foundation as a Fellow.

\section{Acknowledgements}

173 I am indebted to KC Burns for his mentorship early in my academic career. I thank Ewen

174 Cameron and all staff at the Auckland War Memorial Museum for providing access to the

175 remarkable Herbarium. I am grateful have had access to the decades-worth of specimens

176 collected by the Auckland Botanical Society. Lastly, I thank J. Schmack for her ongoing love 177 and support.

\section{References}

180 [1] Baeckens, S. \& Van Damme, R. 2020 The island syndrome. Current Biology 30, R338181 R339.

182 [2] Burns, K.C. 2019 Evolution in isolation: the search for an island syndrome in plants, 183 Cambridge University Press.

184 [3] Whittaker, R.J. \& Fernández-Palacios, J.M. 2007 Island biogeography: ecology, evolution, 185 and conservation, Oxford University Press.

186 [4] Monroy, P. \& García-Verdugo, C. 2019 Testing the hypothesis of loss of defenses on 187 islands across a wide latitudinal gradient of Periploca laevigata populations. American journal 188 of botany 106, 303-312.

189 [5] Holdaway, R. \& MacPhee, R. 1999 Extinctions in near time: Causes, contexts, and 190 consequences.

191 [6] Blackburn, T.M., Cassey, P., Duncan, R.P., Evans, K.L. \& Gaston, K.J. 2004 Avian extinction and mammalian introductions on oceanic islands. Science 305, 1955-1958.

193 [7] Blumstein, D.T. \& Daniel, J.C. 2002 Isolation from mammalian predators differentially 194 affects two congeners. Behavioral Ecology 13, 657-663.

195 [8] Cooper Jr, W.E., Pyron, R.A. \& Garland Jr, T. 2014 Island tameness: living on islands 196 reduces flight initiation distance. Proceedings of the Royal Society B: Biological Sciences 281, 19720133019.

198 [9] Carlquist, S. 1974 Island biology. Columbia University Press, New York.

199 [10] Kavanagh, P.H. 2015 Herbivory and the evolution of divaricate plants: structural defences 200 lost on an offshore island. Austral Ecology 40, 206-211.

201 [11] Vourc'h, G., Martin, J.-L., Duncan, P., Escarré, J. \& Clausen, T.P. 2001 Defensive adaptations of Thuja plicata to ungulate browsing: a comparative study between mainland and island populations. Oecologia 126, 84-93.

204 [12] Cooper, S.M. \& Ginnett, T.F. 1998 Spines protect plants against browsing by small climbing mammals. Oecologia 113, 219-221.

206 [13] Cooper, S.M. \& Owen-Smith, N. 1986 Effects of plant spinescence on large mammalian herbivores. Oecologia 68, 446-455.

208 [14] Bowen, L. \& Van Vuren, D. 1997 Insular endemic plants lack defenses against herbivores. 209 Conservation Biology 11, 1249-1254.

210 [15] Kavanagh, P.H., Shaw, R.C. \& Burns, K.C. 2016 Potential aposematism in an insular tree species: are signals dishonest early in ontogeny? Biological Journal of the Linnean Society 118, 951-958. 
bioRxiv preprint doi: https://doi org/10.1101/2021.11.11.468197; this version posted November 12, 2021. The copyright holder for this preprint (which was not certified by peer review) is the author/funder, who has granted bioRxiv a license to display the preprint in perpetuity. It is made available under aCC-BY-NC-ND 4.0 International license.

\section{LOSS OF DEFENSE IN PLANTS}

213 [16] Fadzly, N. \& Burns, K. 2010 Hiding from the ghost of herbivory past: evidence for crypsis

214 in an insular tree species. International journal of plant sciences 171, 828-833.

215 [17] Burns, K. \& Dawson, J.W. 2009 Heteroblasty on Chatham Island: a comparison with New

216 Zealand and New Caledonia. New Zealand Journal of Ecology, 156-163.

217 [18] AGRAWAL, A. 1997 Do leaf domatia mediate a plant-mite mutualism? An experimental test of the effects on predators and herbivores. Ecological Entomology 22, 371-376.

219 [19] Agrawal, A.A. \& Karban, R. 1997 Domatia mediate plantarthropod mutualism. Nature $220387,562-563$.

221 [20] Grostal, R. \& O'Dowd, D.J. 1994 Plants, mites and mutualism: leaf domatia and the abundance and reproduction of mites on Viburnum tinus (Caprifoliaceae). Oecologia 97, 308315.

224 [21] Brouwer, Y.M. \& Clifford, H.T. 1990 An annotated list of domatia-bearing species. Notes from the Jodrell Laboratory, 1-33.

226 [22] Lin, S., Niklas, K.J., Wan, Y., Hölscher, D., Hui, C., Ding, Y. \& Shi, P. 2020 Leaf shape

227 influences the scaling of leaf dry mass vs. area: a test case using bamboos. Annals of Forest

228 Science 77, 1-15.

229 [23] Wickham, H. 2017 The tidyverse. R package ver 1, 836.

230 [24] Simberloff, D. 1981 What makes a good island colonist? In Insect life history patterns 231 (pp. 195-205, Springer.

232 [25] Cox, B.T.M. \& Burns, K. 2017 Convergent evolution of gigantism in the flora of an 233 isolated archipelago. Evolutionary Ecology 31, 741-752.

234 [26] Emerson, B. 2002 Evolution on oceanic islands: molecular phylogenetic approaches to 235 understanding pattern and process. Molecular ecology 11, 951-966.

236 [27] Welch, J.J. 2009 Testing the island rule: primates as a case study. Proceedings of the Royal 237 Society B: Biological Sciences 276, 675-682.

238 [28] Biddick, M., Hendriks, A. \& Burns, K. 2019 Plants obey (and disobey) the island rule.

239 Proceedings of the National Academy of Sciences 116, 17632-17634.

240 [29] Biddick, M., Hutton, I. \& Burns, K. 2019 Independent evolution of allometric traits: A 241 test of the allometric constraint hypothesis in island vines. Biological Journal of the Linnean 242 Society 126, 203-211.

243 [30] Gibbs, G.W. 2006 Ghosts of Gondwana: the history of life in New Zealand, Craig Potton 244 Publishing. 
bioRxiv preprint doi: https://doi.org/10.1101/2021.11.11.468197; this version posted November 12, 2021. The copyright holder for this preprint (which was not certified by peer review) is the author/funder, who has granted bioRxiv a license to display the preprint in perpetuity. It is made available under aCC-BY-NC-ND 4.0 International license.

\section{LOSS OF DEFENSE IN PLANTS}

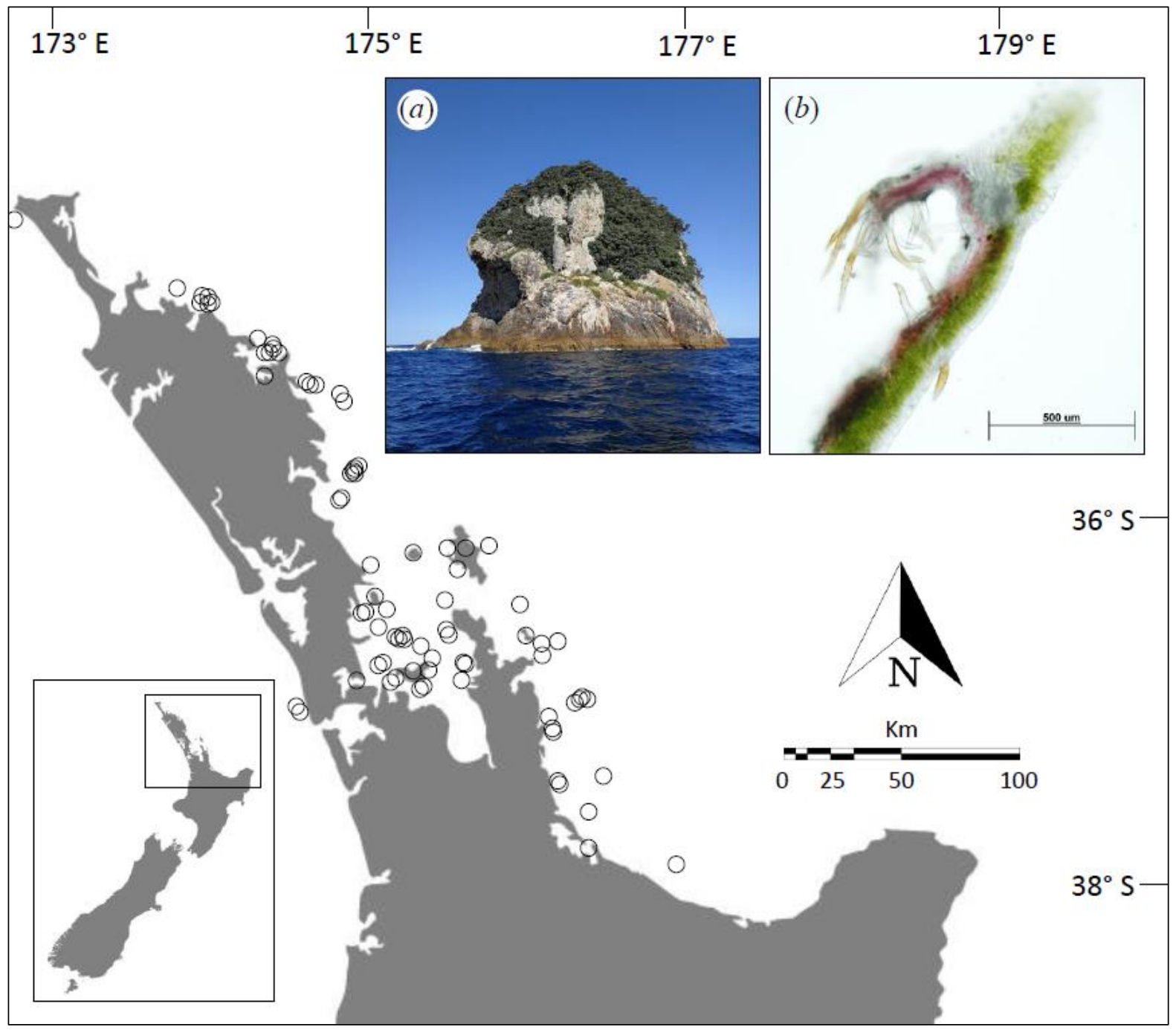

Figure 1. Study area. (a) Remote islands off the east coast of the New Zealand 'mainland' were used to test the loss of defense hypothesis. (b) Leaf domatia are cave-like structures produced on the underside of leaves that facilitate a defensive mutualism with predacious and fungivorous mites (example of tuft domatia in Carpodetus serratus shown, photo credit: Morgan Ngata). Open circles denote individual offshore islands. 
bioRxiv preprint doi: https://doi.org/10.1101/2021.11.11.468197; this version posted November 12, 2021. The copyright holder for this preprint (which was not certified by peer review) is the author/funder, who has granted bioRxiv a license to display the preprint in perpetuity. It is made available under aCC-BY-NC-ND 4.0 International license.

\section{LOSS OF DEFENSE IN PLANTS}

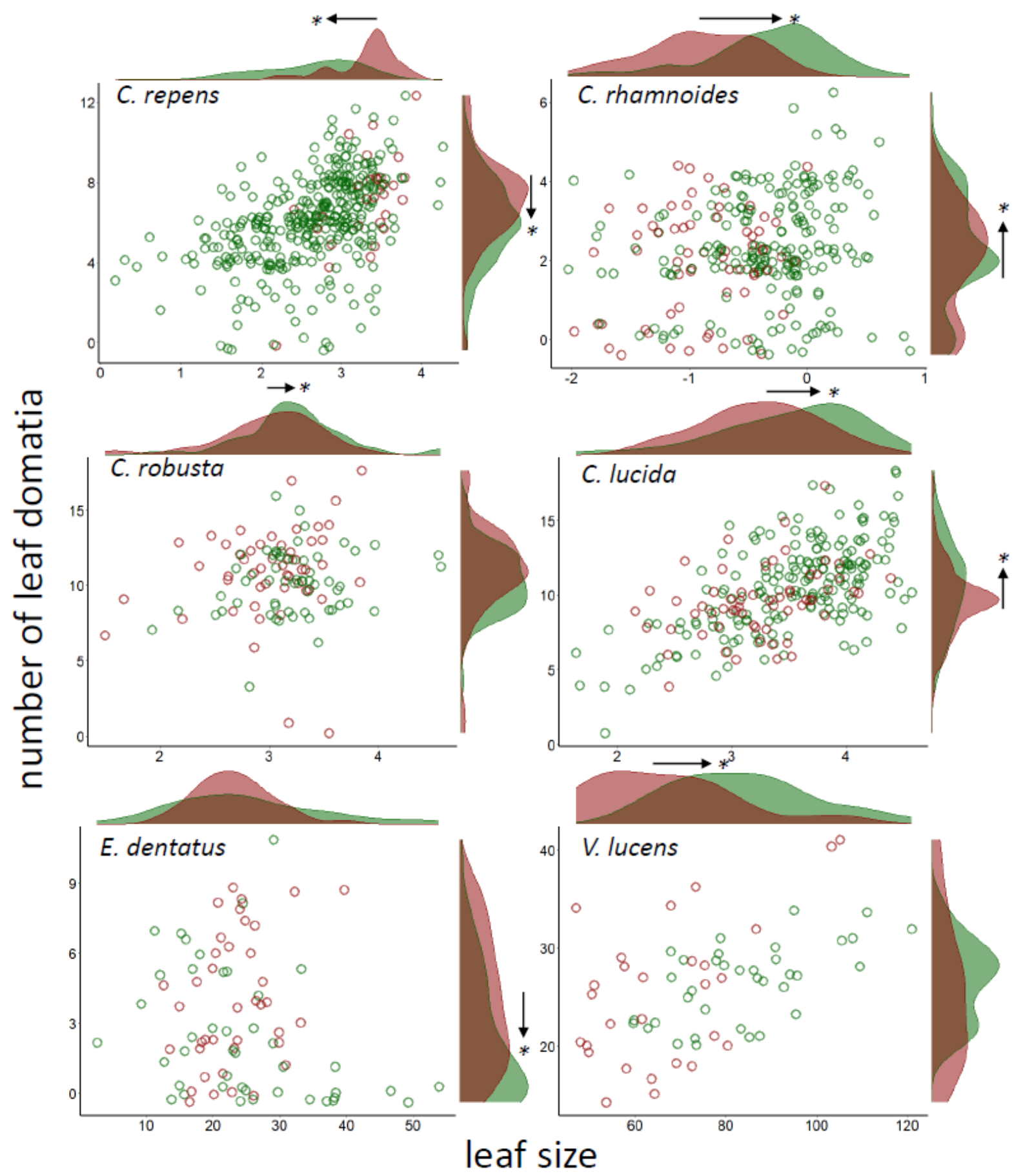

253 Figure 2. Leaf domatia production ( $y$-axis) and leaf size ( $x$-axis, logarithm-transformed) in 254 six cosmopolitan plant taxa inhabiting the New Zealand mainland (red) and its offshore islands 255 (green). Black arrows and asterisks denote significance and direction of change in each trait on islands. 